\title{
IdeAs
}

Idées d'Amériques

$17 \mid 2021$

Villes et culture dans les Amériques

\section{The American Library in Paris: An Unlikely Library Marks 100 Years of Service}

\section{Audrey Chapuis}

\section{(2) OpenEdition \\ 1 Journals}

\section{Electronic version}

URL: https://journals.openedition.org/ideas/11108

DOI: $10.4000 /$ ideas. 11108

ISSN: 1950-5701

\section{Publisher}

Institut des Amériques

\section{Electronic reference}

Audrey Chapuis, "The American Library in Paris: An Unlikely Library Marks 100 Years of Service", IdeAs [Online], 17 | 2021, Online since 01 March 2021, connection on 06 June 2021. URL: http:// journals.openedition.org/ideas/11108; DOl: https://doi.org/10.4000/ideas.11108

This text was automatically generated on 6 June 2021.

\section{(c) (i) (9)}

IdeAs - Idées d'Amériques est mis à disposition selon les termes de la licence Creative Commons Attribution - Pas d'Utilisation Commerciale - Pas de Modification 4.0 International. 


\title{
The American Library in Paris: An Unlikely Library Marks 100 Years of Service
}

\author{
Audrey Chapuis
}

\section{9: A Paris Library}

1 On a Sunday afternoon in the fall of 1919, almost one year from the signing of the armistice, a meeting had been called to determine the fate of the American Library, sometimes referred to by its staff and habitués simply as the Paris Library. As it stood then, in incongruously sumptuous surroundings on 10, rue de l'Élysée, its very existence - one-part book waystation, one-part lending library - was improbable, its future highly uncertain.

2 Like the American soldiers for whom it had been designed, it was presumed that the contents of the Library would soon be shipped home after a long wait. In a sense, the Paris Library was simply an extremely well-appointed camp library, one of thirty-six that had been erected by the Library War Service (LBS), an immense initiative spearheaded by the American Library Association (ALA). Through the service, an estimated two million books and five million periodicals were sent to France during the war, all volumes passing through Paris on their way to makeshift buildings which served 464 military bases, training camps, and hospitals.

In the interim between the war's end and that Sunday afternoon, Paris had grown fond of this English-language library. Not only American servicemen browsed the open stacks (an uncommon feature of European libraries at the time), but an array of Parisians had also become accustomed to its comfortable reading rooms, robust collection of international magazines and newspapers, and thousands of books in English.

4 There had been no plan for a permanent library, but a vision had begun to take shape among its administrators, among them Burton Stevenson, a respected librarian and 
novelist from Ohio who was then serving as the European director of the LWS. The idea was that the American Library in Paris might serve not only as a lending library, but also as a living memorial to the soldiers who had fought in the war, as well as a testament to the LBS effort, to which almost every public library in the United States contributed. Some believed the Library could also serve as a functional model for American library methods. As imagined, librarians from all over Europe would flock to the Library to witness the practicality of the Dewey decimal system and learn about the benefits of open browsing and other new features that broke with traditional practices.

The Sunday meeting was a test of the Library's place in the heart of the city. Would the Library's readers come? And if they did, would they be willing to support it financially? It was estimated that the Library would need one hundred and fifty thousand francs to get on firm footing. Would the American Library Association itself recognize the Paris Library's burgeoning potential? As described in a short, but marvelous account of the Library's origins written by Stevenson, "The future of the Library was very much in doubt."

6 On that fall day, when the shadow of war had only recently begun to recede, the Library was quickly crowded with readers eager to learn of its fate. After several advocates delivered pleas for the Library's continuation, the first reader to declare his support was one of the most important figures in the history of the Library. Charles Seeger, the father of the famous poet Alan Seeger who had died in action, pledged to contribute all the royalties from his son's work to the Library. Other prominent personages in the community, including the heads of the American Chamber of Commerce, the American Woman's Club, and the American University Union, followed suit and were joined by French supporters from every walk of life, from museum curators to literature teachers and students. Large and small pledges flooded in.

7 The show of support was surprising and surpassed the original goal. Indeed, it was substantial enough for the ALA to provide an additional endowment, sign over the deed of the premises, and lead the way to the Library's incorporation in 1920. A motto was chosen: "Atrum Post Bellum, Ex Libris Lux" - After the darkness of war, the light of books.

\section{0: A Virtual Library}

8 Three days before an executive order called for the closure of libraries and other cultural institutions in France on 14 March 2020, the staff of the American Library called an emergency meeting to discuss how the Library should respond to the growing COVID-19 public health crisis.

One hundred years after its founding, the American Library serves close to five thousand members from over sixty countries, though forty percent of its users are American and twenty-two percent are French. It holds the largest collection of English language materials on the European continent and is wholly community supported, receiving no government funding from the US or France (although it did receive subsidies during particularly turbulent periods in its history, as when France provided 100,000 francs during the Great Depression). It is now as much a community and cultural center as it is a library, and its users are as diverse as its collections.

On any given day, one might find designers browsing archival fashion magazines from the 1930s; strollers parked three deep in the aisles while parents and children attend 
Story Hour; and gaggles of teenagers studying for the Baccalauréat in the main reading room. After decades looking for a permanent home, the Library moved to its present location on 10 rue du Général Camou, a quiet side street a stone's throw from the Eiffel Tower, in 1964. It now holds close to 100,000 volumes on its three floors and circulates roughly 115,000 books a year, about the same number of annual checkouts as its early days. Its most popular collections include young adult fiction, adult fiction, biography, travel, cookbooks, and history. Its print holdings are supplemented by electronic collections, but use of print materials still far outpaces that of digital resources.

11 In the twenty-first century, with the populace daily deluged with a tidal wave of information twenty-four hours a day, libraries can be an anchoring force. Beyond book lending, they provide community and opportunities for civic discourse. Their program offerings are now as important as their collections. For example, public library visits in the United States are increasing year after year, even at institutions where book circulation is waning. COVID poses a tangible, imminent public health threat and also an existential one for many cultural institutions whose meaning is derived from inperson interaction and engagement.

During the confinement, a global network of librarians shared insights about how institutions could serve the public even when their doors were closed. At the American Library, in a matter of days, key services and programs were moved online. Virtual library programs and online engagement were offered as palliatives against isolation. By the end of the spring confinement period, digital use doubled.

The Library's founders had witnessed the twin devastations of the war and the 1918 Influenza epidemic. They recognized the solace of books in a time of crisis. To commemorate this founding spirit, a program called At Home with the Library was organized. Familiar actors and writers filmed themselves reading passages from literary legends who have frequented the Library throughout its history. Alongside the readings, snippets from the Library's storied past were shared: Gertrude Stein and Alice B. Toklas argued in the stacks; Henry Miller wrote the librarians asking for books about Zen Buddhism; Mary McCarthy complained to the director that the Library didn't offer enough copies of her books. With the Library's building closed, its history still hummed, its community continued to come together.

\section{0: A Library of Ideals}

Charles Seeger, whose initial pledge had put the Library on firm footing, became the president of its Board of Trustees. He was emboldened by the prospect that the Library could help expand cross-cultural understanding with the express purpose of "diminish[ing] racial antagonism and national prejudices [...through] a war against ignorance and prejudice" and his belief that a well-informed populace was one of "greater sympathy, tolerance and understanding."

Precisely because of the war, these high-minded ideals had an urgent cast. While the Library's fundraising always had pragmatic aims (securing an endowment, finding a more suitable building, growing the collections, and retaining trained staff), it was also animated by intangible but no less pressing goals. In the nineteenth century, American public libraries had flourished because their proponents fervently believed in the power of public education toward the common good. A generation later, this belief, narrowed to an even finer point, was at the heart of the American Library enterprise. 
An independent library with materials in a different language, would serve as a cultural emissary and a reminder of a sacrifice that transcended national borders, creating what one US Ambassador to France called "an imperishable, invisible sanctuary."

The founders' zeal was earnest and even, at times, downright brazen, as they described the Library as a messenger from the New World to the Old. Over the years, some of their bright ambitions were realized, others flared only briefly, and yet others never ignited.

From the beginning, the Library strove for its leadership to be represented by both American and French figures. Its Board remained predominantly American, but its Advisory Council was mostly French and included such luminaries as Marshal Joffre and Raymond Poincaré. That cross-cultural dialogue was paramount to the idea of the Library as both a "messenger of peace" and as a site for innovation in the library profession.

Burton Stevenson, who had played an instrumental role in the Library's founding, served as its director from 1925 to 1930, and the second half of the Library's first decade was one of remarkable growth. The hardscrabble need for funds, however, persisted and ingenious ways to secure materials and even to staff its ranks were devised.

In a mutually beneficial arrangement, the Library worked with sixty-five leading publishers in the United States, who sent free copies of newly published works which the Library displayed in a dedicated exhibition space. Over a thousand new books per year were acquired through this channel, comprising around twelve percent of acquisitions. Meanwhile, Library staff, showing a penchant for publicity, wrote widely published literary reviews of the new titles, and in 1924, they launched their own literary journal called Ex Libris, to which Ernest Hemingway and Gertrude Stein contributed.

Some of the Library's greatest early successes were the relationships it formed with other institutions. It served as a bustling interlibrary loan hub in its then modern "Extension Service" that served libraries throughout Europe. It also maintained close ties with the American Committee for Devastated France, which, alongside the ALA, administered an influential library school that took place at the American Library. Those students later propagated those very library methods which the founders had wished to share with the wider world.

21 The Library also cultivated partnerships with organizations that aided material selection, including the NAACP and the American Association of University Women. It worked with Paris-based institutions as well, including the Bibliothèque Nationale de France and L'Heure Joyeuse, the famous children's library, for Story Hour before founding its own children's department in 1928.

Staffing at the Library was unusual because of its emphasis on having librarians trained in American methods. The majority of the staff came to work on short-term leaves of absence or sabbaticals from American institutions, although some prolonged their stays. The staff lists from the era read like a directory of US libraries. A snapshot from 1930: Dorothy Reeder from the Library of Congress; Helen A. Kirwin from the New York Public Library; Doris Holt from Cleveland Public Library; Mary Moser from Chicago Public Library. The Library benefited from this pool of highly qualified staff. 
, Stevenson thought that the Library had fallen short in some of its more scholarly objectives. Although the Library's extension service and international reference service were sources of pride, there was a constant tension between providing research resources and appeasing the rapacious popular appetite for fiction, a collection which at one point had been hidden away on an upper floor so that patrons might focus more on nonfiction downstairs. He himself revealed an unabashed disdain for novels (perhaps rather surprising for a novelist), because he thought that its presence undermined the Library's more distinguished aim to serve as a site for public education and as a repository of democratic ideals.

\section{0: A Community Library}

As an independent, community-supported nonprofit, the American Library in Paris has withstood major institutional challenges throughout its existence. And, like the city in which it resides, it has witnessed a century of political and societal upheaval. Because libraries are fundamentally social institutions, change will always be a constant. The safeguarding of history and the propulsion toward innovation are two balancing features of library work, and recent global events have thrown both into distinct relief.

Reflecting on the Library's history-the founders' fervent humanitarian impulse, their vision of cross-cultural understanding and their belief in the power of an informed populace-brings consolation at a time of enormous uncertainty. Indeed, the impassioned case made one hundred years ago for the Library's existence is remarkably familiar, as is the community's rallying support.

\section{BIBLIOGRAPHY}

American Library Association, "War Service Library Book. " [Online]

The American Library in Paris Yearbooks 1922-1930.

Maack, Mary Niles, “American Bookwomen in Paris during the 1920s” Libraries \& Culture, 40, n 3, Summer 2005, p. 399-415.

Maack, Mary Niles, “Americans in France: Cross-Cultural Exchange and the Diffusion of Innovations," The Journal of Library History (1974-1987), 21, n² 2, Spring 1986, p.315-33.

Maack, Mary Niles, “'I Cannot Get Along without the Books I Find Here': The American Library in Paris during the War, Occupation, and Liberation, 1939-1945," Library Trends, 53, n³, December 2007, p. 490-512.

McCarthy, Justin, “In U.S., Library Visits Outpaced Trips to Movies in 2019” GALLUP (January 24, 2020). [Online]

Seeger, Charles, "The American Library in Paris: An Account of its Origin, Growth, and Purposes," New York, 1925.

IdeAs, $17 \mid 2021$ 
Stevenson, Burton, “Some Reminiscences of the Paris Library," Library Journal, 69, July 1944, p. 573-78.

Thomas, Susan Otis, "The American Library in Paris: An International Development in the American Library Movement," The Library Quarterly: Information, Community, Policy, 34, $\mathrm{n}^{\circ} 2$, April 1964, p. 179-90.

Wright, Christopher, "April - And the American Library - In Paris," American Libraries 6, no 4, April 1975, p. 226-27.

Young, Arthur P. Books for Sammies: The American Library Association and World War I, Beta Phi Mu chapbook n $15,1981$.

\section{AUTHOR}

\section{AUDREY CHAPUIS}

Audrey Chapuis has served as director of the American Library in Paris since 2018 and has been working in libraries for close to twenty, most notably at Widener Library in the Harvard College Library system and the Pritzker Legal Research Center at the Northwestern University School of Law, where she was head of the Access Services department. She received her Master's in Library and Information Science from the University of Illinois in 2006 and her ALB in Extension Studies from Harvard University. chapuis@americanlibraryinparis.org 